\title{
Chemical attributes of soils with eggshell application
}

\section{Atributos químicos de solos com aplicação de casca de ovo}

\author{
José Ricardo MANTOVANI'; Matheus Esteves Rocha FERREIRA²; Anderson Romão dos SANTOS²; \\ Belchior de Souza COSTA²; Ligiane Aparecida FLORENTINO 3 \\ ${ }^{1}$ Autor para correspondência, Docente, Doutor, Universidade José do Rosário Vellano - Unifenas, Faculdade de Agronomia, \\ Rodovia MG 179, km 0, Caixa Postal 23, Alfenas, MG - mantovanijß@yahoo.com \\ ${ }^{2}$ Discentes de Agronomia, Universidade José do Rosário Vellano - matheusrochaef@hotmail.com; \\ anderson.romao.santos@hotmail.com; belchior.costa@outlook.com \\ ${ }_{3}^{3}$ Docente, Doutora, Universidade José do Rosário Vellano - ligiane.florentino@unifenas.br
}

Recebido em: 17-01-2017; Aceito em: 13-02-2017

\begin{abstract}
Eggshell is an industrial residue which can be used as an acidity corrective, but its employment must follow some criteria. The objective of the present work was to evaluate the effect of eggshell on fertility attributes of soils with different clay contents. The experiment was conducted under laboratory conditions, from September to December 2015. A completely randomized design was used in a $2 \times 6$ factorial scheme, with two additional treatments and four replications, totaling 56 experimental units. The treatments were composed by the combination of two soils with different texture classes (sandy and clayey) and six doses $\left(0,1,2,3,4\right.$ and $\left.5 \mathrm{t} \mathrm{ha}^{-1}\right)$ of eggshell, based on the volume of soil used. In the additional treatments, dolomitic limestone was used in each soil, instead of eggshell, aiming to raise their initial base saturation (V\%) to $70 \%$. Portions of $0.25 \mathrm{dm}^{3}$ of each soil received the doses of eggshell or limestone, being then moistened to $70 \%$ of the water retention capacity and remaining in incubation for 60 days. After the incubation, the $\mathrm{pH}$ in $\mathrm{CaCl}_{2}$, the potential acidity $(\mathrm{H}+\mathrm{Al})$ and the soil contents of $\mathrm{P}$, extracted by Mehlich, $\mathrm{K}^{+}, \mathrm{Ca}^{2+}, \mathrm{Mg}^{2+}$ e $\mathrm{Al}^{3+}$ were evaluated. Eggshell corrects the acidity and increases the $\mathrm{Ca}^{2+}$ and $\mathrm{Mg}^{2+}$ levels, especially in sandy soil, yet less efficiently than limestone.
\end{abstract}

Additional keywords: acidity; calcium; liming; residue.

\section{Resumo}

A casca de ovo é um resíduo da indústria que pode ser utilizado como corretivo de acidez, mas seu emprego deve seguir critérios. O objetivo do presente trabalho foi avaliar o efeito da casca de ovo em atributos de fertilidade de solos com diferentes teores de argila. O experimento foi conduzido em condições de laboratório, no período de setembro a dezembro de 2015. Empregou-se delineamento inteiramente ao acaso, em esquema fatorial $2 \times 6$, com dois tratamentos adicionais e quatro repetições, totalizando 56 unidades experimentais. Os tratamentos foram constituídos por combinação de dois solos com diferentes classes texturais (arenoso e argiloso) e seis doses $\left(0 ; 1 ; 2 ; 3 ; 4\right.$ e $\left.5 \mathrm{t} \mathrm{ha}^{-1}\right)$ de casca de ovo, com base no volume de solo empregado. Nos tratamentos adicionais, ao invés de casca de ovo, foi utilizado, em cada solo, calcário dolomítico, visando a elevar a saturação por bases inicial (V\%) de cada solo a $70 \%$. Porções de $0,25 \mathrm{dm}^{3}$ de cada solo receberam as doses de casca de ovo ou o calcário, foram umedecidas a $70 \%$ da capacidade de retenção de água e permaneceram em incubação por 60 dias. Após a incubação, foram avaliados o $\mathrm{pH}$ em $\mathrm{CaCl}_{2}$, a acidez potencial $(\mathrm{H}+\mathrm{Al})$ e os teores de $\mathrm{P}$, extraídos por Mehlich, $\mathrm{K}^{+}, \mathrm{Ca}^{2+}, \mathrm{Mg}^{2+}$ e Al ${ }^{3+}$ dos solos. A casca de ovo corrige a acidez e aumenta os teores de $\mathrm{Ca}^{2+}$ e $\mathrm{Mg}^{2+}$, especialmente em solo arenoso, mas de forma menos eficiente do que 0 calcário.

Palavras-chave adicionais: acidez; calagem; cálcio; resíduo.

\section{Introduction}

The increase in the agroindustrial activity has led to the generation of large quantities of waste in the last decades, which, when disposed in an inadequate manner, can have negative impacts on the environment (Souza et al., 2014). The composition of these residues depends on the raw material, but many of them have potential for use in agriculture, and employment according to technical criteria presents benefits, such as the supply of nutrients to the plants and the correction of soil acidity (Guimarães et al., 2012).

Eggshell powder is an abundant waste generated in the industry of egg products and derivatives, and the most common final destination of this material is landfill disposal (Magalhães et al., 2011). Considering that the shell comprises about $10 \%$ of the whole egg (King'ori, 2011), and that in Brazil, more than 8.5 billion eggs are produced annually (Silveira et al., 2016), it is observed that large quantities of this residue are generated in the country. 
Chicken eggshell contains about $40 \% \mathrm{Ca}$ in the form of calcium carbonate, and could be used in agriculture as a soil acidity corrective or as a source of the nutrient in food and feed (King'ori, 2011; Milbradt et al., 2015). In agriculture, Magalhães et al. (2011) found that the application of eggshell increased the $\mathrm{pH}$ of two soils with different clay contents. Silveira et al. (2016) found that the use of eggshell as a source of $\mathrm{Ca}^{2+}$, in doses equivalent to up to $390 \mathrm{~kg} \mathrm{ha}^{-1} \mathrm{Ca}^{2+}$, did not increase the dry matter yield of shoots of the Piatã and Marandu forage grasses, moreover, it did neither alter the nutrient contents in the shoots of the Piatã grass, nor the bromatological composition of the Marandu grass. However, there is a need for more information on the effects of eggshell on soil and plants.

The agricultural productivity in tropical regions is influenced mainly by factors related to soil acidity, and limestone is the main acidity corrective agent used in agriculture (Natale et al., 2012). According to these authors, soil acidity correction promotes the neutralization of $\mathrm{Al}^{3+}$, increased $\mathrm{pH}$ and the supply of $\mathrm{Ca}$ and $\mathrm{Mg}$, which allows root proliferation, with positive effects on shoot growth.

Considering the above, the objective of the present work was to evaluate the effect of eggshell on fertility attributes of soils with different clay contents.

\section{Material and methods}

The experiment was conducted under laboratory conditions, from September to December 2015. For such, it was used a sample of the superficial layer $(0$ to $20 \mathrm{~cm})$ of two soils, one of sandy texture, classified as Ultisol and another with a clayey texture, classified as Oxisol. After the collection, the sample of each soil was separately air and shade dried, ground, sieved with a 4-mm mesh screen and homogenized. The initial routine chemical characterization (Silva, 2009) and the granulometric characterization were performed in a subsample of each soil (Camargo et al., 2009), whose values are presented in Table 1.

Table 1 - Chemical and granulometric characterization of the soils used in the experiment.

\begin{tabular}{|c|c|c|c|c|c|c|c|c|}
\hline Soil & $\mathrm{pH}$ & OM & P-Mehlich & $\mathrm{K}^{+}$ & $\mathrm{Ca}^{2+}$ & $\mathrm{Mg}^{2+}$ & $\mathrm{Al}^{3+}$ & $\mathrm{H}+\mathrm{Al}$ \\
\hline & $\mathrm{CaCl}_{2}$ & $\left(\mathrm{~g} \mathrm{dm}^{-3}\right)$ & $\left(\mathrm{mg} \mathrm{dm}^{-3}\right)$ & ---- & -1 & $\mathrm{~mol}_{\mathrm{c}} \mathrm{d}$ & & ---- \\
\hline Sandy & 4.5 & 18 & 1 & 0.6 & 3 & 2 & 1 & 20 \\
\hline \multirow[t]{2}{*}{ Clayey } & 4.2 & 21 & 3 & 0.9 & 5 & 2 & 6 & 44 \\
\hline & $\begin{array}{l}\text { SB } \\
(\mathrm{mm}\end{array}$ & $\begin{array}{l}\text { CEC } \\
\left.n^{-3}\right)\end{array}$ & $\begin{array}{l}\text { V } \\
-\cdots--(c\end{array}$ & $\begin{array}{l}m \\
m\end{array}$ & $\begin{array}{l}\text { P-rem } \\
\left(\mathrm{mg} \mathrm{L}^{-1}\right)\end{array}$ & sand & $\begin{array}{c}\text { silt } \\
\mathrm{g} \mathrm{kg}^{-1}\end{array}$ & clay \\
\hline Sandy & 6 & 26 & 23 & 14 & 32 & 812 & 69 & 119 \\
\hline Clayey & 8 & 52 & 15 & 43 & 9 & 290 & 135 & 575 \\
\hline
\end{tabular}

$\mathrm{OM}=$ organic matter; $\mathrm{H}+\mathrm{Al}=$ potential acidity; $\mathrm{SB}=$ sum of bases; $\mathrm{CEC}-$ cation exchange capacity at $\mathrm{pH} 7.0 ; \mathrm{V}=$ base saturation; $\mathrm{m}=$ aluminium saturation; P-rem = remaining phosphorus.

A completely randomized design was used, in a $2 \times 6$ factorial scheme, with two additional treatments and four replications, totaling 56 experimental units. The treatments consisted of the combination of two soils with different clay contents and six doses of eggshell powder: $0 ; 0.13 ; 0.26 ; 0.39 ; 0.52$ and $0.65 \mathrm{~g}$ flask $^{-1}$, corresponding to $0,1,2,34$ and $5 \mathrm{t} \mathrm{ha}^{-1}$, based on the volume of soil used and on the volume of the $0-20 \mathrm{~cm}$ layer, of 1 ha $\left(2,000,000 \mathrm{dm}^{3}\right)$. In the additional treatments, instead of eggshell, dolomitic limestone $(\mathrm{CaO}=39 \%, \mathrm{MgO}=13 \%, \mathrm{NP}=102 \%$, RNP $=91 \%$ ) was used to raise the initial base saturation (V) of each soil to $70 \%$. Thus, the limestone doses in the additional treatments were 0.16 and 0.39 $\mathrm{g}$, corresponding to 1.3 and $3.1 \mathrm{t} \mathrm{ha}^{-1}$ in the sandy and clayey soil, respectively, based on the volume of soil used.

The eggshell used in the experiment was obtained in an industry of egg processing, pasteurization and dehydration, located in Nepomuceno-MG. After its achievement, the eggshell is ground in the generating industry itself, being obtained a powdered residue. The eggshell used in the experiment was analyzed according to Tedesco et al. (1995) and the values, on a dry basis, are shown in Table 2 .
Table 2 - Chemical composition of the eggshell used in the experiment.

\begin{tabular}{lc}
\hline Parameters & Values \\
\hline Moisture $\left(\mathrm{g} \mathrm{kg}^{-1}\right)$ & 5.8 \\
$\mathrm{pH}$ & 8.1 \\
$\mathrm{C}$-organic $\left(\mathrm{g} \mathrm{kg}^{-1}\right)$ & 0 \\
$\mathrm{~N}\left(\mathrm{~g} \mathrm{~kg}^{-1}\right)$ & 5.3 \\
$\mathrm{P}\left(\mathrm{g} \mathrm{kg}^{-1}\right)$ & 0.9 \\
$\mathrm{~K}\left(\mathrm{~g} \mathrm{~kg}^{-1}\right)$ & 3.8 \\
$\mathrm{Ca}\left(\mathrm{g} \mathrm{kg}^{-1}\right)$ & 268 \\
$\mathrm{Mg}\left(\mathrm{g} \mathrm{kg}^{-1}\right)$ & 4.1 \\
$\mathrm{~S}\left(\mathrm{~g} \mathrm{~kg}^{-1}\right)$ & 0.8 \\
$\mathrm{~B}\left(\mathrm{mg} \mathrm{kg}^{-1}\right)$ & 2 \\
$\mathrm{Cu}\left(\mathrm{mg} \mathrm{kg}^{-1}\right)$ & 2 \\
$\mathrm{Fe}\left(\mathrm{mg} \mathrm{kg}^{-1}\right)$ & 30 \\
$\mathrm{Mn}\left(\mathrm{mg} \mathrm{kg} \mathrm{g}^{-1}\right)$ & 0.9 \\
$\mathrm{Zn}\left(\mathrm{mg} \mathrm{kg}^{-1}\right)$ & 0.8 \\
\hline
\end{tabular}

The density of each soil was determined, whose values were: 1.41 and $1.06 \mathrm{~kg} \mathrm{dm}^{-3}$, for sandy and clayey texture, respectively. Subsequently, portions equivalent to $0.25 \mathrm{dm}^{3}$ of each soil were weighed and received the doses of eggshell or limestone according to the treatments. After mixing the soil portions with the doses of eggshell or limestone, they were transferred to plastic flasks with a capacity of 
$0.3 \mathrm{dm}^{3}$, moistened with distilled water to about $70 \%$ of the retention capacity, and remained in incubation for 60 days. During incubation, soil moisture control was performed every 2 days, by weighing the flasks and replacing the water, in order to maintain the initial moisture content of the soils.

At the end of the incubation, soil portions were collected from the flasks and air-dried, and a soil sample was collected from each flask for the analyses of $\mathrm{pH}$ in $\mathrm{CaCl}_{2}$, potential acidity and $\mathrm{P}$-Mehlich, $\mathrm{K}^{+}$, $\mathrm{Ca}^{2+}, \mathrm{Mg}^{2+}$ and $\mathrm{Al}^{3+}$ contents (Silva, 2009). The results were submitted to analysis of variance using the $F$ test and polynomial regression analysis was performed using the statistical program Agroestat (Barbosa \& Maldonado Júnior, 2015). The comparison, within each soil, between the treatments that received the doses of eggshell and the additional treatment was done by unfolding the degrees of freedom of the treatments, through the method of contrasts.

\section{Results and discussions}

The eggshell and soil types significantly influenced $(\mathrm{p}<0.01)$ the $\mathrm{pH}$, the potential acidity $(\mathrm{H}+\mathrm{Al})$ and the $\mathrm{Ca}^{2+}, \mathrm{Mg}^{2+}$ and $\mathrm{Al}^{3+}$ levels in the soils (Table $3)$. There was interaction of the factors evaluated regarding these chemical attributes, which indicates that the effect of eggshell on these attributes was dependent on the soil used. Notwithstanding, the application of the residue did not change ( $p>0.05)$ the $\mathrm{P}$ and $\mathrm{K}$ contents in the soils, whose mean values were, respectively, $1 \mathrm{mg} \mathrm{dm}^{-3}$ and $0.4 \mathrm{mmol}_{\mathrm{c}} \mathrm{dm}^{-3}$ for sandy texture, and $3 \mathrm{mg} \mathrm{dm}^{-3}$ and $1 \mathrm{mmol}_{\mathrm{c}} \mathrm{dm}^{-3}$ for clayey texture. The low levels of $P$ and $K$ in the eggshell explain the results obtained in relation to these nutrients in the soils.

Table 3 - F values, coefficients of variation and significance of the chemical attributes evaluated in soils with different clay contents as a function of eggshell doses.

\begin{tabular}{|c|c|c|c|c|c|c|c|}
\hline Causes of variation & $\mathrm{pH}$ & $\mathrm{H}+\mathrm{Al}$ & $\mathrm{P}$ & $\mathrm{K}^{+}$ & $\mathrm{Ca}^{2+}$ & $\mathrm{Mg}^{2+}$ & $\mathrm{Al}^{3+}$ \\
\hline Soil (S) & $279.00^{\star *}$ & $257.69^{* *}$ & $256.00^{\star \star}$ & $915.06^{\star *}$ & $552.25^{\star *}$ & $108.30^{* *}$ & $682.67^{\star *}$ \\
\hline Eggshell doses (D) & $189.03^{* *}$ & $98.31^{* *}$ & $2.58 \mathrm{NS}$ & $2.48 \mathrm{NS}$ & $204.99^{* *}$ & $37.29^{* *}$ & $44.89^{\star \star}$ \\
\hline$S \times D$ & $8.41^{\star *}$ & $16.18^{\star *}$ & 2.42NS & $2.65 N S$ & $21.29^{\star *}$ & $4.31^{* *}$ & $44.89^{\star *}$ \\
\hline CV (\%) & 1.73 & 5.31 & 12.20 & 9.03 & 11.27 & 9.39 & 14.81 \\
\hline
\end{tabular}

NS and ${ }^{* *}$ correspond respectively to not significant $(p>0.05)$ and significant $(p<0.01)$, by $F$ test.

There was an increase in the $\mathrm{pH}$ and a decrease in the potential acidity of the sandy and clayey soils with eggshell doses (Figures $1 \mathrm{~A}$ and 1B). According to the regression equations, there was an increase of 1.1 and 0.7 units in the $\mathrm{pH}$ of the sandy and clayey soils, respectively, with the application of $5 \mathrm{t} \mathrm{ha}^{-1}$ eggshell. Thus, the soil acidity varied from high to low in sandy soil and from very high to medium in clayey soil, according to the classes of interpretation presented in Raij et al. (1997). Regarding $\mathrm{H}+\mathrm{Al}$, there

A.

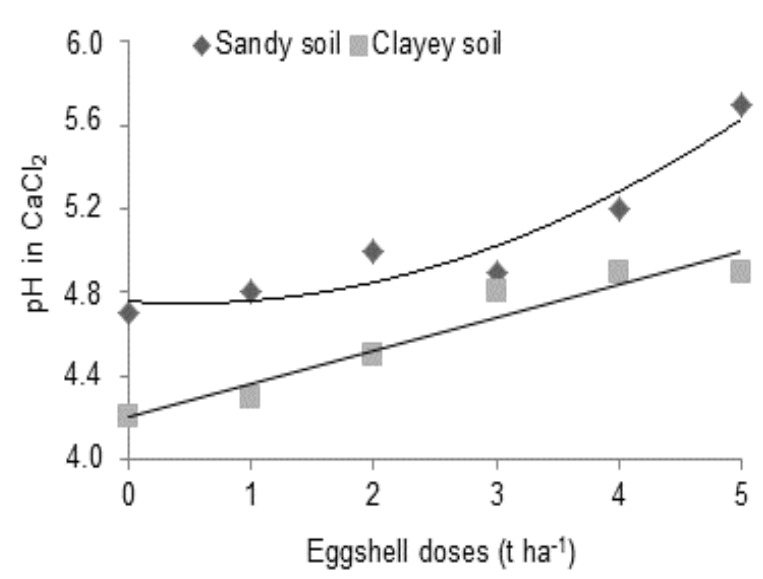

y sandy soil $=0.0446 x^{2}-0.036 x+4.730 ; R^{2}=0.933^{* *}$

$y$ clayey soil $=0.165 x+4.194 ; R^{2}=0.953^{\star *}$ was a decrease of $34 \%$ and $23 \%$ in this attribute in the sandy and clayey soils, when comparing the control treatment with the one that received the highest dose of the residue. These results indicate that the application of eggshell provided a correction in the acidity of the soils, and that the corrective effect was higher in the sandy soil than in the clayey soil. The lower buffering power of the sandy soil, due to the lower CEC of this soil in relation to the clayey soil, explains these results.

B.

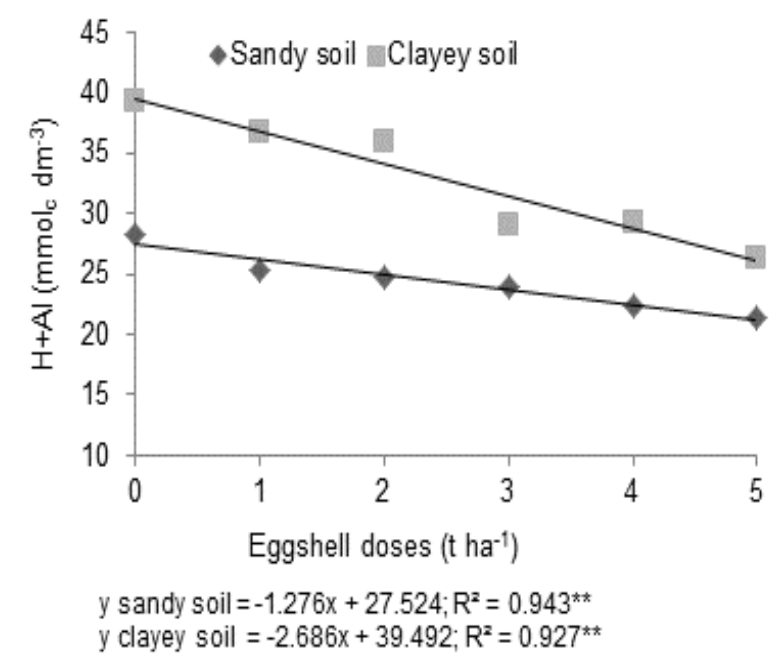

Figure 1 - Effect of eggshell on $\mathrm{pH}(\mathrm{A})$ and potential acidity $(\mathrm{H}+\mathrm{Al})(\mathrm{B})$ of sandy and clayey soil. 
The soil acidity correction that occurs with the eggshell application is due to $\mathrm{CaCO}_{3}$, which is the main component of this residue (Milbradt et al., 2015), being also present in the limestone. In the soil, $\mathrm{CaCO}_{3}$ dissolves in bicarbonate $\left(\mathrm{HCO}_{3}{ }^{-}\right)$, hydroxyl $\left(\mathrm{OH}^{-}\right)$and $\mathrm{Ca}^{2+}$. Hydroxyl reacts with the $\mathrm{H}^{+}$ion of the soil solution, resulting in $\mathrm{H}_{2} \mathrm{O}$, and $\mathrm{HCO}_{3}{ }^{-}$also reacts with $\mathrm{H}^{+}$, generating $\mathrm{H}_{2} \mathrm{O}$ and $\mathrm{CO}_{2}$. Therefore, the soil acidity is gradually neutralized (Raij, 2011).

Similar results regarding the neutralization of soil acidity were also obtained by Branco et al. (2013); Lasso et al. (2013); Raymundo et al. (2013) and Giostri et al. (2014), using different types of residue. Branco et al. (2013) verified an increase in the $\mathrm{pH}$ and a decrease in the potential acidity of two soils with different clay contents $\left(142\right.$ and $\left.390 \mathrm{~g} \mathrm{~kg}^{-1}\right)$ with the application of doses of alkaline solid waste from the paper and cellulose industry. According to these authors, the soil acidity correction occurred due to the high amount of carbonates and hydroxides present in this residue. Raymundo et al. (2013) detected that residues obtained in marble sawdust (rock powders) have potential for use as soil acidity corrective. The authors obtained a linear increase in the $\mathrm{pH}$ and a decrease in the potential acidity of the soil with the addition of these residues. Lasso et al. (2013) verified that the application of civil construction and demolition waste, from concretes, cement and hauling, sieved in a 2-mm mesh, corrected the soil acidity, since there was an increase in the $\mathrm{pH}$ and a decrease in the value of $\mathrm{H}+\mathrm{Al}$. Giostri et al. (2014) verified, under field conditions, an increase in the soil $\mathrm{pH}$, with high buffering power, after the application of up to $180 \mathrm{~m}^{3} \mathrm{ha}^{-1}$ of liquid waste from the enzyme industry.

The $\mathrm{Al}^{3+}$ content of the clayey soil decreased with eggshell application (Figure 2). In this soil, the $\mathrm{Al}^{3+}$ content ranged from 6.3 (control) to $1.8 \mathrm{mmol}_{\mathrm{c}} \mathrm{dm}^{-3}$ (highest dose of the residue), which corresponded to a decrease of 3.5 times. In the sandy soil, there was no significant variation in the $\mathrm{Al}^{3+}$ content with the use of eggshell doses, due to the fact that the initial content of this element in the soil was very low $\left(1 \mathrm{mmol}_{\mathrm{c}} \mathrm{dm}^{-3}\right)$. With the increase in soil $\mathrm{pH}$ there is a decrease in the $\mathrm{Al}^{3+}$ content due to the formation of the precipitate $\mathrm{Al}$ $(\mathrm{OH})_{3}$, non-toxic to plants (Raij, 2011).

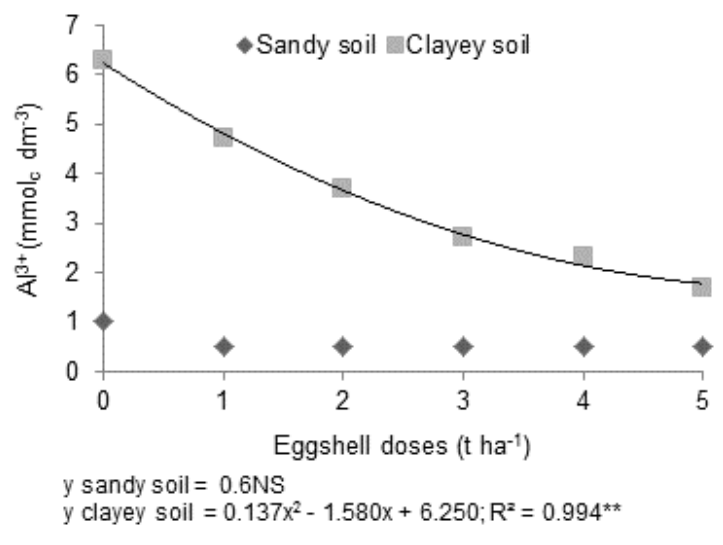

Figure 2 - Effect of eggshell on $\mathrm{Al}^{3+}$ content of sandy and clayey soil.

Pértile et al. (2012) also observed a decrease in the $\mathrm{Al}^{3+}$ content in the soil, as a consequence of the acidity correction with the addition of alkaline waste from the cellulose industry. The high level of $\mathrm{Al}^{3+}$ in the soil, a frequent condition in tropical regions, provides short, thick, fragile roots, with thick apices and brown coloration, which impairs the absorption and accumulation of nutrients in the plants (Gama \& Kiehl, 1999; Mota et al., 2016).

The $\mathrm{Ca}^{2+}$ and $\mathrm{Mg}^{2+}$ contents increased with eggshell application, both in sandy and in clayey soils (Figures $3 \mathrm{~A}$ and $3 \mathrm{~B}$ ). Regarding $\mathrm{Ca}^{2+}$, the content ranged from 1 to $8 \mathrm{mmolc}_{\mathrm{cm}} \mathrm{dm}^{-3}$ in the sandy soil, and from 5 to $14 \mathrm{mmolc}_{\mathrm{cm}}{ }^{-3}$ in the clayey soil, when comparing the control treatment with the one that received the higher dose of eggshell. Thus, $\mathrm{Ca}^{2+}$ contents varied from low to high in sandy soil and from medium to high in clayey soil, according to the classes of interpretation presented in Raij et al. (1997), and increased 8 and 3 times, respectively, in sandy and clayey soils. The presence of high concentrations of $\mathrm{Ca}$ in the eggshell explains these results.

Increases in the $\mathrm{Ca}^{2+}$ content in the soil with the application of different inorganic residues, such as those from the cellulose industry, granite processing and paper recycling, were also obtained by several authors (Albuquerque et al., 2011; Guarçoni \& Fanton, 2011; Balbinot Júnior et al., 2014). In plants, calcium is a component of the cell wall, acting on the stabilization of cell membranes, on the enzymatic activation, cell division, root growth, pollen germination and pollen tube growth (Raij, 2011; Domingues et al al., 2016). Therefore, calcium deficiency in plants causes a decrease in plant height, number of leaves and leaf area, in addition to chlorosis and bifurcated growth of plants (Leal \& Prado, 2008).

With the application of $5 \mathrm{t} \mathrm{ha}^{-1}$ eggshell, $\mathrm{Mg}^{2+}$ levels increased 5 and 1.5 times in relation to the control, in the sandy and clayey soils, respectively. Hence, nutrient contents ranged from 1 to $5 \mathrm{mmol}_{\mathrm{c}} \mathrm{dm}^{-3}$ 
in the sandy soil and from 4 to $6 \mathrm{mmol}_{\mathrm{c}} \mathrm{dm}^{-3}$ in the clayey soil, values classified as low and medium for both soils, considering the classes of contents presented in Raij et al. (1997). Medeiros et al. (2009) also observed an increase in $\mathrm{Mg}^{2+}$ and $\mathrm{Ca}^{2+}$ levels in the soil with the addition of alkaline waste from the paper and cellulose industry at the soil surface.
A.

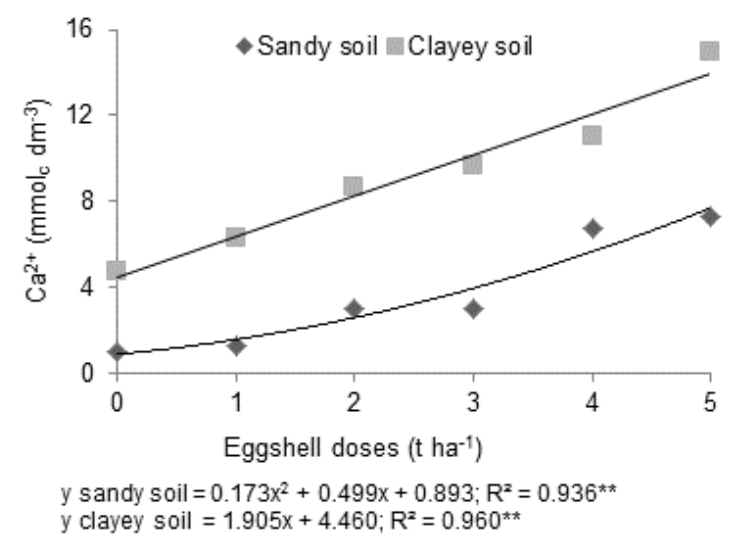

B.

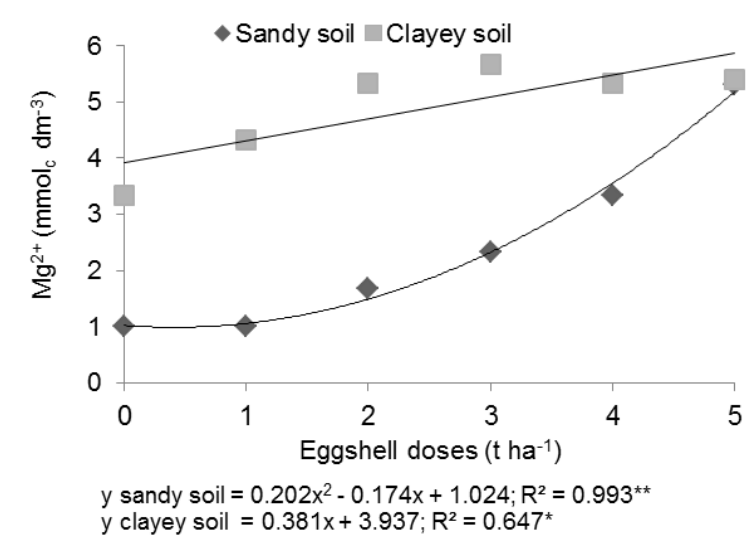

Figure 3 - Effect of eggshell on $\mathrm{Ca}^{2+}(\mathrm{A})$ and $\mathrm{Mg}^{2+}(\mathrm{B})$ contents of sandy and clayey soil.

In the additional treatment, which received limestone instead of eggshell doses, the chemical attributes determined were different from those of the treatments that received the residue in both sandy and clayey soils (Table 4). The $\mathrm{pH}$ value and the $\mathrm{Ca}^{2+}$ and $\mathrm{Mg}^{2+}$ content in the treatment that received dolomitic limestone aiming to raise the $\mathrm{V}$ of the soils to $70 \%$ were, respectively, 6.0; 12 and $6 \mathrm{mmol}_{\mathrm{c}} \mathrm{dm}^{-3}$ in sandy soil, and 5.6; 26 and $11 \mathrm{mmol}_{\mathrm{c}} \mathrm{dm}^{-3}$ in clayey, values higher than those obtained in all treatments receiving eggshell doses, even with the limestone dose being lower than most doses of the residue. The $\mathrm{H}+\mathrm{Al}$ values in the additional treatment with limestone were 17 and $16 \mathrm{mmol}_{\mathrm{c}} \mathrm{dm}^{-3}$ in sandy and clayey soils, respectively, being lower than in treatments with eggshell application.

Table 4 - Test $F$ values of the contrasts comparing within each soil additional limestone treatment with eggshell doses and chemical attributes values in the additional treatment.

\begin{tabular}{|c|c|c|c|c|c|c|c|}
\hline \multirow{2}{*}{ Contrasts } & \multicolumn{6}{|c|}{ Eggshell doses $\left(\mathrm{t} \mathrm{ha}^{-1}\right)$} & \multirow{2}{*}{ Limestone } \\
\hline & 0 & 1 & 2 & 3 & 4 & 5 & \\
\hline \multicolumn{8}{|c|}{$\begin{array}{l} \\
\end{array}$} \\
\hline $\mathrm{pH}$ & $735.44^{\star *}$ & $598.94^{\star *}$ & $448.00^{* *}$ & $505.75^{\star *}$ & $252.00^{* *}$ & $35.44^{\star *}$ & 6,0 \\
\hline $\mathrm{H}+\mathrm{Al}$ & $76.34^{* *}$ & $41.27^{\star *}$ & $34.93^{* *}$ & $29.12^{* *}$ & $16.91^{* *}$ & $11.16^{* *}$ & $17 \mathrm{mmol}$ \\
\hline $\mathrm{Ca}^{2+}$ & $275.69^{* *}$ & $258.73^{* *}$ & $182.00^{* *}$ & $182.00^{* *}$ & $60.58^{\star *}$ & $45.50^{* *}$ & $12 \mathrm{mmol}_{\mathrm{c}} \mathrm{dm}^{-3}$ \\
\hline $\mathrm{Mg}^{2+}$ & $179.20^{* *}$ & $179.20^{* *}$ & $137.20^{* *}$ & $100.80^{* *}$ & $56.70^{\star *}$ & $6.30^{*}$ & $6 \mathrm{mmol}_{\mathrm{c}} \mathrm{dm}^{-3}$ \\
\hline \multicolumn{8}{|c|}{ 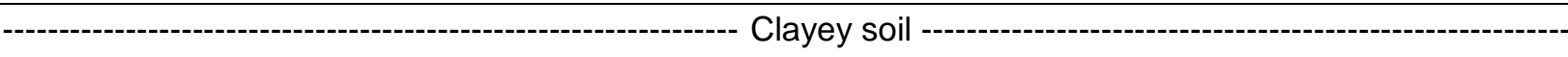 } \\
\hline $\mathrm{pH}$ & $268.43^{\star *}$ & $219.74^{\star *}$ & $175.91^{* *}$ & $95.11^{* *}$ & $60.87^{\star \star}$ & $60.87^{\star *}$ & 5,6 \\
\hline $\mathrm{H}+\mathrm{Al}$ & $551.36^{* *}$ & $434.11^{* *}$ & $406.98^{* *}$ & $175.00^{* *}$ & $183.86^{* *}$ & $112.00^{* *}$ & $16 \mathrm{mmol}_{\mathrm{c}} \mathrm{dm}^{-3}$ \\
\hline $\mathrm{Ca}^{2+}$ & $603.98^{* *}$ & $511.91^{* *}$ & $395.80^{\star *}$ & $350.61^{* *}$ & $294.61^{* *}$ & $155.83^{* *}$ & $26 \mathrm{mmolc}_{\mathrm{c}} \mathrm{dm}^{-3}$ \\
\hline $\mathrm{Mg}^{2+}$ & $67.76^{\star *}$ & $50.54^{* *}$ & $35.84^{\star \star}$ & $31.50^{* *}$ & $35.84^{\star *}$ & $35.84^{\star *}$ & $11 \mathrm{mmol}_{\mathrm{c}} \mathrm{dm}^{-3}$ \\
\hline $\mathrm{Al}^{3+}$ & $210.58^{* *}$ & $114.33^{\star *}$ & $70.58^{\star *}$ & $37.33^{\star *}$ & $28.58^{* *}$ & $14.58^{\star *}$ & $0 \mathrm{mmol}_{\mathrm{c}} \mathrm{dm}^{-3}$ \\
\hline
\end{tabular}

${ }^{*}$ and ${ }^{* *}$ correspond respectively to significant $(p<0.05)$ and significant $(p<0.01)$ by contrasts test.

With this, it was found that eggshell was less efficient than limestone in correcting soil acidity and in providing $\mathrm{Ca}^{2+}$ and $\mathrm{Mg}^{2+}$. Magalhães et al. (2011) also reported that the application of limestone in soils with high buffering power resulted in a higher $\mathrm{pH}$ increase when compared to the use of eggshell. According to the authors, this occurred due to the lower granulometry of the limestone particles in relation to the eggshell.

\section{Conclusion}

Eggshell corrects the acidity and increases the $\mathrm{Ca}^{2+}$ and $\mathrm{Mg}^{2+}$ levels, especially in sandy soil, yet less efficiently than limestone.

\section{Acknowledgment}

To the Fundation of the State of Minas Gerais (Fapemig) for financial suppor. 


\section{References}

Albuquerque JA, Medeiros JC, Costa A, Rengel M (2011). Aplicação de resíduo alcalino na superfície de cambissolos. Bragantia 70(4):888-898.

Balbinot Júnior AA, Veiga $M$, Fonseca JA, Vogt GA, Albuquerque JA, Costa ERO (2014). Aplicação de resíduo de reciclagem de papel em cambissolo háplico e seu efeito no solo e no cultivo de plantas. Revista Brasileira de Ciência do Solo 38(1):336-344.

Barbosa JC, Maldonado Júnior W (2015). Experimentação agronômica e AgroEstat: sistema para análises estatísticas de ensaios agronômicos. Jaboticabal/Multipress. 396p.

Branco SB, Silveira CB, Campos ML, Gatiboni LC, Miquelluti DJ (2013). Atributos químicos do solo e lixiviação de compostos fenólicos após adição de resíduo sólido alcalino. Revista Brasileira de Engenharia Agrícola e Ambiental 17(5):543-550.

Camargo AO, Moniz AC, Jorge JA, Valadares JMAS (2009). Métodos de análise química, mineralógica e física de solos do Instituto Agronômico de Campinas. Campinas/Instituto Agronômico. 77p. Boletim Técnico 106.

Domingues LS, Ribeiro ND, Andriolo JL, Possobom MTDF, Zemolin AEM (2016). Growth, grain yield and calcium, potassium and magnesium accumulation in common bean plants as related to calcium nutrition. Acta Scientiarum. Agronomy 38(2):207-217.

Gama JRNF, Kiehl JC (1999). Influência do alumínio de um podzólico vermelho-amarelo do Acre sobre o crescimento das plantas. Revista Brasileira de Ciência do Solo 23(2):475-482.

Giostri AF, Bond LFM, Motta ACV, Pimentel IC, Carvalho PCF, Dionísio JA (2014). The effects of industrial waste from enzyme production on pasture growth and soil chemical properties. Acta Scientiarum. Agronomy 36(2):247-257.

Guarçoni MA, Fanton CJ (2011). Resíduo de beneficiamento de granito como fertilizante alternativo na cultura do café. Revista Ciência Agronômica 42(1):16-26.

Guimarães RC, Cruz MCP, Ferreira ME, Taniguchi CAK (2012). Chemical properties of soils treated with biological sludge from gelatina industry. Revista Brasileira de Ciência do Solo 36(2):653-660.

King'ori AM (2011). A review of the uses of poultry eggshells and shell membranes. International Journal of Poultry Science 10(11):908-912.

Lasso PRO, Vaz CMP, Bernardi ACC, Oliveira CR, Bacchi OOS (2013). Avaliação do uso de resíduos de construção e demolição reciclados como corretivo de acidez do solo. Revista Brasileira de Ciência do Solo 37(6):1659-1668.

Leal RM, Prado RM (2008). Desordens nutricionais no feijoeiro por deficiência de macronutrientes, boro e zinco. Revista Brasileira de Ciências Agrárias 3(4):301-306.
Magalhães MC, Ribeiro AR, Quina M, Cameira C, Soares M (2011). Tratamento e valorização agrícola da casca de ovo. Revista de Ciências Agrárias 34(2):191-204.

Medeiros JC, Albuquerque JA, Mafra AL, Batistela F, Grah J (2009). Calagem superficial com resíduo alcalino da indústria de papel e celulose em um solo altamente tamponado. Revista Brasileira de Ciência do Solo 33(6):1657-1665

Milbradt BG, Müller ALH, Silva JS, Lunardi JR, Milani LIG, Flores EMM, Callegaro MGK, Emanuelli T (2015). Casca de ovo como fonte de cálcio para humanos: composição mineral e análises bromatológicas. Ciência Rural 45(3):560-566.

Mota MFC, Pegoraro RF, Batista PSC, Pinto VO, Maia VM, Silva DF (2016). Macronutrients accumulation and growth of pineapple cultivars submitted to alluminum stress. Revista Brasileira de Engenharia Agrícola e Ambiental 20(11):978-983.

Natale W, Rozane DE, Parent LE, Parent SE (2012). Acidez do solo e calagem em pomares de frutíferas tropicais. Revista Brasileira de Fruticultura 34(4):12941306.

Pértile P, Albuquerque JA, Gatiboni LC, Costa A, Warmling MI (2012). Application of alcaline waste from pulp industry to acid soil with pine. Revista Brasileira de Ciência do Solo 36(3):939-950.

Raij B (2011). Fertilidade do solo e manejo de nutrientes. Piracicaba/International Plant Nutrition Institute. 420p.

Raij B, Cantarella H, Quaggio JA, Furlani AMC (1997). Recomendações de adubação e calagem para 0 Estado de São Paulo. 2.ed.rev.atual. Campinas/Instituto Agronômico, Fundação IAC. 285p. Boletim Técnico 100.

Raymundo V, Neves MA, Cardoso MSN, Bregonci IS, Lima JSS, Fonseca AB (2013). Resíduos de serragem de mármores como corretivo da acidez de solo. Revista Brasileira de Engenharia Agrícola e Ambiental 17(1):47-53.

Silva FC (2009). Manual de análises químicas de solos, plantas e fertilizantes. 2.ed.rev.atual. Brasília/ Embrapa Informação Tecnológica. 627p.

Silveira NH, Rabelo FHS, Rezende AV, Rabelo CHS, Bianchini HC (2016). Eggshell as a source of calcium in the production, nutrition and bromatological composition of Piatã and Marandu grasses. Revista Brasileira de Engenharia Agrícola e Ambiental 20(2):113-118.

Souza HA, Rozane DE, Amorim DA, Modesto VC, Natale W (2014). Uso fertilizante do subproduto da agroindústria processadora de goiabas. I. Atributos químicos do solo. Revista Brasileira de Fruticultura 36(3):713-724.

Tedesco MJ, Gianello C, Bissani CA, Bohnen $H$, Volkweiss SJ (1995). Análises de solo, plantas e outros materiais. Porto Alegre/UFRGS. 174p. Boletim Técnico 5. 